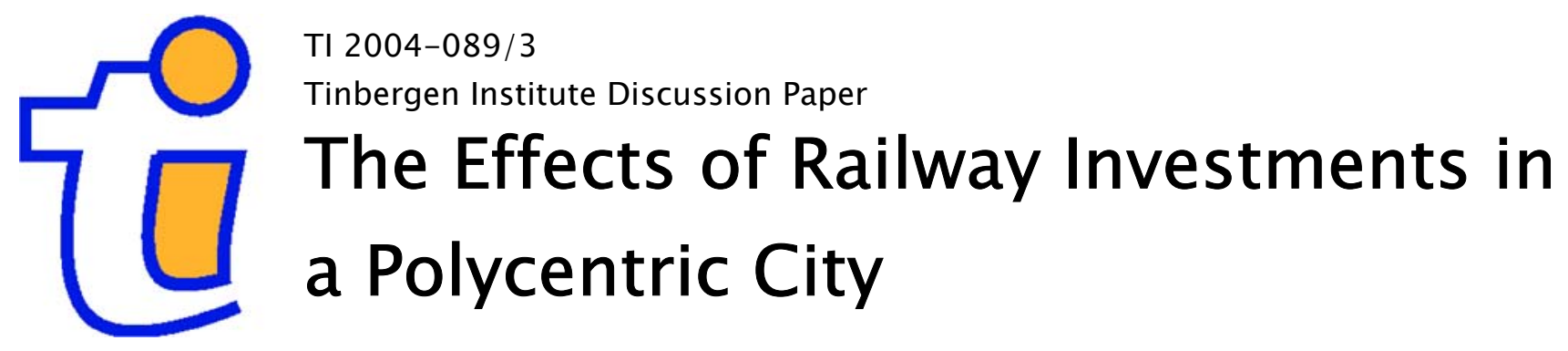

Ghebreegziabiher Debrezion *

Eric Pels

Piet Rietveld*

Faculty of Economics and Business Administration, Vrije Universiteit Amsterdam.

* Tinbergen Institute. 


\section{Tinbergen Institute}

The Tinbergen Institute is the institute for economic research of the Erasmus Universiteit Rotterdam, Universiteit van Amsterdam, and Vrije Universiteit Amsterdam.

Tinbergen Institute Amsterdam

Roetersstraat 31

1018 WB Amsterdam

The Netherlands

Tel.: $\quad+31(0) 205513500$

Fax: $\quad+31(0) 205513555$

Tinbergen Institute Rotterdam

Burg. Oudlaan 50

3062 PA Rotterdam

The Netherlands

Tel.: $\quad+31(0) 104088900$

Fax: $\quad+31(0) 104089031$

Please send questions and/or remarks of nonscientific nature to driessen@tinbergen.nl.

Most TI discussion papers can be downloaded at http://www.tinbergen.nl. 


\title{
The Effects of Railway Investments in a Polycentric City
}

\author{
Ghebreegziabiher Debrezion \\ Eric Pels \\ Piet Rietveld \\ Free University, Department of Spatial Economics \\ De Boelelaan 1105, 1081 HV Amsterdam
}

April 2004

\begin{abstract}
This paper analyses the effect of railway investment on land prices and land use in a polycentric city under various regulatory regimes of land markets. The introduction of a faster mode of transport (train), accessible in discrete locations leads to an extended city size. The stations of the "fast" mode attract dense residential settlements. As a result, the average residential and commercial land rents increase in both the competitive and segmented land market situations, as compared with the "slow" unimodal transport case. When rail investments only serve one particular centre, this leads to the growth of the advantaged centre at the expense of the other centre. Generally speaking, investment in the fast mode results in city growth and increase in rent receipts. However the effect of the investment for individual centres and their corresponding residential areas depends on the underlying land market assumptions and the level of investment. Distorted land markets lead to increases in commercial rents, but this is more than off-set by the decrease in residential land rent.
\end{abstract}

\section{Key words:}

Bimodal urban model, bicentric city, commercial land rent, residential land rent, railway station, railway development. 


\section{INTRODUCTION}

The car has gradually become the dominant transport mode in most cities of developed countries. However, there still are cities, such as London, Paris and New York, where a large part of the workers use public transport. Therefore, to make a proper analysis of land and labour markets in such cities, both transport modes should be considered. Many cities started with a clear monocentric structure. During the course of time, however, a gradual deconcentration process took place, leading to a decreasing dominance of the original centre. But, in some cases, edge cities have developed, implying the emergence of additional centres of commercial activity in a metropolitan area (Garreau, 1988). In other cases, the gradual growth of small- and medium-sized cities led to the evolution of large metropolitan areas consisting of overlapping urban areas that were formerly independent. In both these cases of city evolution, the original monocentric urban model no more applies. This paper sets out to study both phenomena in an urban model which deal with the combination of multiple transport modes and multiple centres of economic activity.

In the urban modelling, in relation to the type of centre and mode of transport assumptions, we can logically distinguish four categories: monocentric-unimodal transport; monocentricmultimodal transport; polycentric-unimodal transport; and polycentric-multimodal transport. Most of the literature is in line with the first category, although recently, more and more studies that make the polycentric assumption have appeared. But these are still dominated by the unimodal transport assumption. In the contrary, this paper can be characterized as a study in the last of the four above mentioned category. We deal with an urban model of multiple centres and multiple transport modes. This can be considered as an extension to the literature, since we deal with two modes of transport in the model. The additional mode of transport addressed here (railway) is more in line with public transport. It operates from discrete locations that are represented by stations. Accordingly, we will use the terms "fast mode" and "train" interchangeably. The goal of this paper is to develop an urban model with an emphasis on the impact of investment in transportation on the real estate market. Thus, this paper assesses the effect of investment on rail in the spatial rent structure. Moreover, this will help us to assess the effects of an additional transport system (rail) on urban grow the in general, and the growth of particular sub-centres. In addition, this paper assesses the effect of partial railway investment on the competitive position between centres within the city. Previously, Sasaki (1989) has addressed the effect of change in a competing bimodal transport system on the monocentric urban structure. The transport modes differ in cost structure. He concluded that the effect of change in transport 
modes is not as unambiguous as it used to be in with the unimodal case. The basic difference between Sasaki's and our approach in dealing the bimodal case pertains to the operation of the modes. In Sasaki's approach, apart from the cost structure, there is no distinction in the operation of the modes, i.e. they operate in a continuous line space. However, in addition to the difference in cost structure we impose additional distinguishing factor in that the 'slow' mode operates in continuous line space whereas the 'fast' mode operates from discrete locations represented by stations. Here we extend Sivitanidou and Wheaton's (1992) model by introducing an additional mode of transport (rail: fast mode with discrete access points) running through the bicentric linear open city. In the model, households and firms interact via the exchange of labour and wages. The differences between our model and that of Sivitanidou and Wheaton (1992) concern aspects such as: the introduction of a second transport mode; endogenous land consumption by households; endogenous density of settlements; and endogenous wages for the two centres.

In subsequent sections we briefly discuss the literature in the area (section 2), discuss the specification of our model (Section 3), and give the equilibrium conditions of the model (Section 4). We then introduce the model for alterative land markets: competitive and segmented (Section 5). The model simulation and results are discussed in Section 6. Finally, we conclude and suggest a direction for future research (Section 7).

\section{LITERATURE REVIEW}

The relation between land values and proximity of land to employment centres has been addressed extensively in the literature. The monocentric circular city has received the most attention. However, in many parts of the world, especially in Western Europe, Japan and the U.S., metropolitan areas are increasingly assuming polycentric structures. The Randstad Holland, Rhine-Ruhr metropolitan area in Germany, the Flemish Diamond in Belgium, the GlasgowEdinburgh region in UK, the Padua-Treviso-Venice region in Italy, Southern California in the U.S. and the Kansai area in Japan are probably the most frequently mentioned polycentric structures (van der Wusten and Faludi, 1992; Dieleman and Faludi, 1998; Batten, 1995; Musterd and van Zelm, 2001). But, even though polycentric urbanization started earlier in Europe than in the U.S., its pace was slowed in Europe as a result of conservative urban policies.

A common conjecture in the literature is that transportation is believed to be the prime factor in shaping the urban structure (Clark and Kuijpers-Linde, 1994). However, the equilibrium location of businesses and households has always been an outcome of the trade-off between production 
economies and transport diseconomies (direct and congestion costs). The transportation side favours dispersed business locations, whereas the production side favours compact business locations. Thus, besides changes on the transportation side, changes on the production side (agglomeration and productivity effects) are also responsible for determining the equilibrium location and thus shaping the urban location (Glaeser and Kahn, 2003). Fujita et al. (1999) tried to theoretically explain the effects of agglomeration on the optimal location of firms in relation to a location of historic centre. In a linear city of unit length, the optimal location of a new plant will be in the historic centre for a wide range of locations. Nevertheless, at times, the optimal location of the plant can be different from the historic centre. The trade-off between agglomeration effects and transportation costs explains the coexistence of multiple centres in a city. In a recent paper, Modarres (2003) found for Los Angeles County that sub-centres contain one-third of the county's employment. However, the transit network structure appears to serve these sub-centres inadequately. This shows that the formation of a polycentric urban structure was not in response to the development of public transit in the first place. On the contrary, the increasing use of private cars is believed to be instrumental in shaping the present dispersed urban structure (Glaeser and Kahn, 2003). In addition to the use of cars, Sivitanidou (1997) showed that the recent information revolution is also contributing towards the weakening of spatial links between commercial activities and large business locations, thereby leading to increasingly dispersed business locations.

Even though polycentricity simply implies the presence of multiple centres in an urban area, there is no proper identification procedure (Anas et al., 1996). For practical purposes, areas can be treated as centres as far as they significantly affect such variables as employment density, population residential density, property values and travel patterns. Several authors have tried to propose ways of identifying centres in cities by both parametric and non-parametric methods. However, these still remain essentially subjective. The main methods of these types are: the residual method of McDonald (1989); the employment density cutoffs method of Giuliano and Small (1991); and the employment smoothing estimation procedure of Craig and $\mathrm{Ng}$ (2001). Later, McMillen (2001) developed a two-stage centre identification procedure, which incorporates concepts of McDonald, and Craig and $\mathrm{Ng}$. In the first stage, candidate centres are identified through the analysis of the residuals of a smoothed employment density function. The second stage assesses the significance of the identified centres in influencing local employment densities. This reflects the definition that centres are sites which result in a significant rise in employment densities after controlling for the historic centre (the CBD). Apart from calculating 
an employment density indicator, Musterd and van Zelm (2001) discussed various ways to define a polycentric city structure. Both spatial structure and the existence of intricate network-type interactions should be present before considering an urban area to be a polycentric unit. They argue that at the household level, polycentric regions the size of the Randstad and the Rhine-Ruhr are too big to constitute a relevant geographical region. However, in another study of the Randstad, Schwanen et al. (2001) found that the level of urban land deconcentration alters a household's modal choice from public transport to private modes.

Several studies have addressed the effect of urban spatial structure on property values. This will also be the main focus of this paper, which attempts to answer the question: How does the polycentricity of an urban area shape the land rent structure? The value of a centre is capitalized in the form of land rents. In addition to the predetermined centre in the urban models, other studies, without explicitly referring to the centre(s), have concluded that the rent gradient peaks around the most valuable location in the urban spatial structure. Indirectly, these peaks are also used to identify the centre(s) of the city. However, in this sense, the monocentric assumption is in reality a very simplistic assumption. Therefore, over the years, attempts have been made to develop urban models in the context of polycentric situations (pre-specified and non-pre-specified locations).

A comprehensive general equilibrium polycentric urban model was developed by Anas and Kim (1996). Without scale economies of shopping, production is dispersed in the city with rent, wage, and commodity price and density gradients peaking in the centre of the space. One of the models on property values in a bicentric city was developed by Sivitanidou and Wheaton (1992). Special attention was given to the centres' production cost difference and commercial land market regulation. The main finding of the paper was that cost advantages are capitalized in commercial land rent and wages (and wages in their turn, in residential land rents). The level of capitalization of production cost advantages in commercial land rent becomes higher in the regulated commercial land market compared with the competitive market. This throws doubt on the application of the hedonic pricing theory to commercial and residential land rents in the context of distorted markets. Therefore, in the present paper we will pay special attention to market distortions. 


\section{THE STRUCTURE OF THE MODEL}

\subsection{Bicentric-Bimodal urban structure: model description}

In this section, we introduce the equilibrium land use model of an urban area that we discuss in this paper. The city in our model has two area occupying centres, $b$ miles apart from each centre's edge. They both function as employment and production centres. Land use in these centres is explicitly modelled. Labour is employed from households living in the residential areas of the city. Each household is assumed to have one member. All households arriving at either of the two centres deliver identical labour. Thus, labour for production is measured in terms of household numbers. The inputs in the production process constitute labour and commercial floor space. In the production process of the centres, we assume a fixed ratio between labour and floor space. Floor space is prepared in a cost-minimizing fashion from land rented at the commercial land rent rate and capital rented at some market rent of capital. The output follows a constant returns to scale technology, and is exported at a given price in a fully competitive market.

The households have a well-behaved utility function. Residential land and non-land consumption goods make up the utility-bearing bundle. By travelling to one of the employment centres, households acquire an endogenously given wage. The residential land rent has a bid nature. The price of non-land consumption goods is taken as a numéraire (unity). In our analysis, no other income sources are considered, apart from the wages. Thus, the household's budget is constrained by wage earnings. All commercial and residential rents are absorbed by absentee land owners. This is one of the elements that make our model a partial equilibrium model.

Two modes of transport operate in the open city: a "slow" mode (car) that is accessible from anywhere in the city, and a "fast" mode (train) accessible from certain fixed stations. The distinction between the "slow" and "fast" modes does not only relate to the time cost of transportation, but rather to the generalized transportation cost structure. The fast mode results in some sort of cost saving, and is thus termed "fast". In our linear city model, as well as at the centres, we assume three additional stations at a distance of $b / 2$ miles from the edges of the centres (see Figure 1 below). To make the bimodal transport approach relevant to our analysis, we assume that the per distance cost of transportation for the fast mode (train) is lower than that of the slow mode. Transportation inside the centres is assumed to be zero. Thus, only transportation costs incurred by the households to reach the edge of the centres are considered. Transportation by households takes place from their residences to the nearest edge of the 
employment centre. Households make use of the transport modes in a way that minimizes generalized transportation costs.

We further assume that the city we deal here with is open: workers are free to migrate into or out of the city. The households enjoy the national utility level $u$ which is bounded from below by the supreme utility level (a level of utility that guarantees the existence of the city). Thus, all households in the city enjoy a given utility level that is equivalent to the level of utility enjoyed by the households outside the city in the economy.

The exogenous parameters of the model can be seen from three sides: namely, the household side; the producer side; and the spatial structure of the city. On the consumer side, we have: national utility level; price of non-land consumption goods; and transportation costs of the modes. On the producer side we have: cost advantage of one centre over the other; floor space requirement per worker; and cost of capital. Lastly, for the spatial structure of the city we have: width of the city and the distance between the nodes, given exogenously to the model. The value of the exogenous variables used in the simulation is given in Table 1. Analysis is provided for two regulatory alternatives for land market situations: competitive and segmented markets.

\subsection{Notation and definition of variables}

The utility functions of the households follow a Cobb Douglas formulation. Centre 1 is assumed as a reference (located at 0 ) for all nodes. Centre 2 is at a location $b$ distance units away from the edge of centre 1. Here, we do not try to find out the optimal distance separating the centres. We take this distance as exogenous to our model and analyse its implication for the land market coupled with transportation investment. The general layout of the city structure is depicted in Figure 1. The two centres occupy a significant land for commercial purposed in the urban area. 


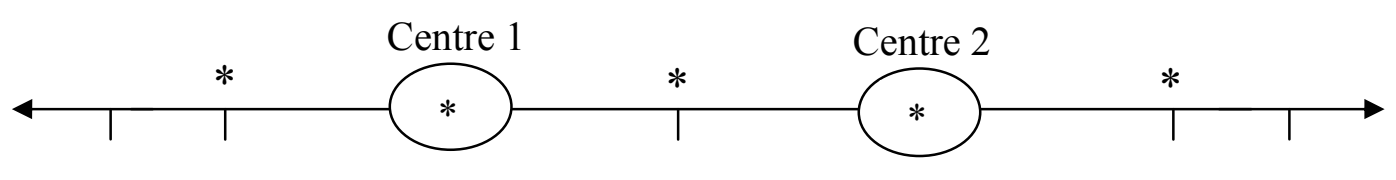

$\begin{array}{lccccccccc}\text { Location } & & -\mathrm{b} / 2 & 0 & \mathrm{~L}_{1} & \mathrm{~L}_{1}+\mathrm{b} / 2 & \mathrm{~L}_{1}+\mathrm{b} & \mathrm{L}_{1}+\mathrm{L}_{2}+\mathrm{b} & \mathrm{L}_{1}+\mathrm{L}_{2}+3 \mathrm{~b} / 2 \\ \text { Variable } & \mathrm{f} & \mathrm{r}_{1} & \mathrm{r}_{2}^{-} & \mathrm{r}_{2}^{+} & \mathrm{r}_{3} & \mathrm{r}_{4}^{-} & \mathrm{r}_{4}^{+} & \mathrm{r}_{5} & \mathrm{f}^{+} \\ \text {Node } & & & & & & & & & \\ \end{array}$

* The location of the railway stations in the linear city

Figure 1: Layout of linear city with two commercial centres, each with its own railway stations and three additional railway stations

In Figure 1, the first row gives the variable representing the location of some critical points in the linear city: namely, the fringes of the city, the edges of the centres and the station locations. The left edge of centre 1 is taken as the origin of the linear city. $L_{1}$ and $L_{2}$ represent the size of the two centres, respectively. According to the land market assumptions, they can be given exogenous to the model or are endogenously determined in the model. This is dealt with in detail in the next section. 
Table 1: Model variables

\begin{tabular}{|c|c|}
\hline Variable & Description \\
\hline$I$ & The set of employment and production centres $I=\{1,2\}$ \\
\hline$J$ & The set of transport nodes $J=\{1,2, . .5\}$, where $I \subseteq J$ \\
\hline$r$ & A variable location in one dimensional space \\
\hline$r_{j}$ & Location of node $j, j \in J$ \\
\hline$u$ & Utility level \\
\hline$w_{i}$ & Wage at centre $i, i \in I$ \\
\hline$Y_{j}^{*}$ & Artificial income at node $j, j \in J$ \\
\hline$R_{A}$ & Rent for agricultural land (the basic land rent) \\
\hline$R C_{i}$ & Commercial land rent at centre $i, i \in I$ \\
\hline$r_{c}$ & Rent of capital (\$/sq. ft.) \\
\hline$R F_{i}$ & Rent for floor space at centre $i, i \in I$ \\
\hline$\Psi_{j}(r, u)$ & Residential bid rent per unit lot size of land corresponding to node $j \in J$, at location $\mathrm{r}$, and u level of utility. \\
\hline$R R(r, u)$ & Prevailing residential rent per unit lot size of land at location $r$ for utility level $u$. \\
\hline$S(r, u)$ & Size of residential land consumed by household at location $r$, the max bid lot size \\
\hline$Z(r, u)$ & $\begin{array}{l}\text { Amount of goods (produced at the centres) consumed at location } \mathrm{r} \text {. We take these goods as a numéraire with } \\
\text { unit price. }\end{array}$ \\
\hline$k_{s}$ & Transportation cost per unit distance for the slow mode \\
\hline$k_{f}$ & Transportation cost per unit distance for the fast mode \\
\hline$T(r)$ & Transportation cost function from location $r$ to the destination centre (node) \\
\hline $\mathrm{N}_{i}$ & Number of employees at centre $i, i \in I$ \\
\hline $\mathrm{Qs}_{i}$ & Floor space at centre $i, i \in I$ \\
\hline$L_{i}$ & Area of commercial land at centre $i$. \\
\hline$K_{i}$ & Amount of capital employed at centre $i, i \in I$ \\
\hline$a_{s}$ & Floor space per workers ratio $\left(\mathrm{Qs}_{\mathrm{i}} / \mathrm{N}_{\mathrm{i}}\right), i \in I$ \\
\hline $\mathrm{CA}$ & Production cost advantage for centre 1. \\
\hline prt & Productivity per worker (units/worker). \\
\hline$l(r, u)$ & Distribution of land in the city. In the linear constant unit width city, it is uniform, given by $l(r, u)=1$. \\
\hline$\rho(\mathrm{r}, \mathrm{u})$ & Density of households of a city at location $r$, corresponding to $u$ level of utility. \\
\hline
\end{tabular}




\section{EQUILIBRIUM CONDITIONS}

\subsection{Households' equilibrium: utility maximization}

Besides to the agricultural land use that starts at the outermost fringes of the city, urban land is devoted to residential and commercial use. The assumption of a land market without any imperfections guarantees that the commercial land rent always outbids the residential land rent in the employment centres. To keep the analysis tractable, we assume transport cost within the centre to be zero, so that the commercial land rent is uniform within the centres. For residential land use, the trade-off between transport costs and other consumption opportunities leads to a downward-sloping bid rent curve from the edge of the centres. Figure 2 depicts the rent structure of a city with one centre. The segment $o c$, is devoted to commercial land use. The segment $c f$, where the residential land rent dominates is the area of the city devoted to residential land use. To the right of $f$, transportation costs reach a level such that the residential rent falls below the agricultural land rent; therefore that area is devoted to agricultural land use. Thus, the land rent curve is an envelope of the curves, as depicted by the figure below.

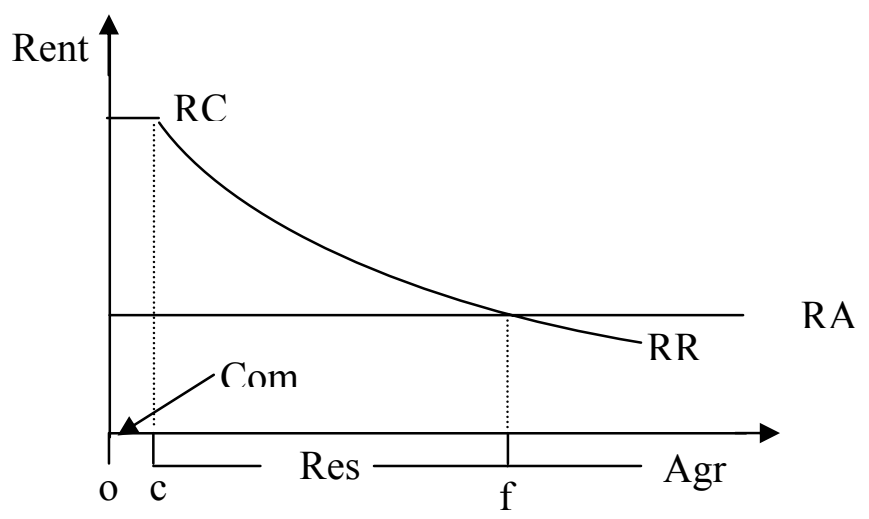

Fig. 2 Land use and land rent curve

The centres are job centres where the individuals earn wages by offering labour. Commuting to the centres is possible by one of the slow or fast mode, or a combination of both these modes. The transportation costs corresponding to the modes of transport represent a generalized cost structure. Thus, comparison between the two modes can follow smoothly. The individuals use the fast and/or slow transport mode in total transportation cost-minimizing fashion in order to reach the centre, where they can earn higher net income (wages minus transport costs). Due to their cost-saving nature, the nodes of transport can function as additional centres that have a corresponding land rent curves. They invite dense residential settlement, if not employment. Apart from the intersection points of the rent curves, at any particular place along the length of 
the linear city, one rent curve will always outbid the others. Thus, the real land rent curve in the city is the envelope of the various land rent curves corresponding to the different nodes.

Below, we give the derivation of a general case residential bid rent function. It is defined by the maximum rent per unit land that a household, at a location $r$, which travels to a specified employment centre to get an income $Y$, can pay while achieving a certain utility level $u$. The bid rent function in the city is a function of the distance and the utility level enjoyed by the households (Fujita, 1989), which can be written as:

$\Psi(r, u)=\max _{z, s}\left\{\frac{Y-T(r)-z}{s} \mid U(z, s)=u\right\}$,

where $\Psi(r, u)$ is the residential land rent, for a household at location $r$ enjoying a given exogenous level of utility $u . U(z, s)$ is the utility function, where $z$ is the composite consumption good of the household that has a unit price, and $s$ is the land lot size per household. The household incurs transportation costs $T(r)$ which is a function of the location $r$ in relation to the location of the employment centre, and receives $Y$ level of income.

Equation (1) can be rewritten by expressing the amount of composite consumption goods of the household in terms of lot size of land and utility:

$$
\Psi(r, u)=\max _{s}\left\{\frac{Y-T(r)-Z(s, u)}{s}\right\}
$$

For a fixed utility level $u$, the FOC for maximizing the right hand side of equation (2) occurs at the point where the marginal change of the function with respect to $s$ is zero. This leads to the relation:

$-\frac{\partial Z(s, u)}{\partial s}=\frac{Y-T(r)-Z(s, u)}{s}$.

At the optimal choice of s the right hand side of (3) equals the bid rent $\Psi(r, u)$ :

$-\frac{\partial Z(s, u)}{\partial s}=\Psi(r, u)$ 
For simplicity and ease of derivation, we assume that the utility function of the household has the following functional form:

$$
U(z, s)=\alpha \ln z+\beta \ln s \quad \alpha+\beta=1 .
$$

The equation of the indifference curve is given as $Z(s, u)=s^{-\beta / \alpha} e^{u / \alpha}$. Solving the maximization problem in (2) using the condition in (3), we have:

$$
\begin{aligned}
& \Psi(r, u)=\alpha^{\alpha / \beta} \beta(Y-T(r))^{1 / \beta} e^{-u / \beta} ; \\
& S(r, u)=\beta(Y-T(r)) / \Psi(r, u)=\alpha^{-\alpha / \beta}(Y-T(r))^{-\alpha / \beta} e^{u / \beta} .
\end{aligned}
$$

\section{Artificial income at nodes}

In order to relate the general bid rent analysis to our bimodal multi-nodal model, we introduce a special income variable. Households travel to the employment centre that maximizes their net income. Thus, they can use the slow mode of transport to directly reach the employment centre of choice or a station, and then use the fast mode of transport to reach the employment centre. The multiple nodes situation in our case implies that these nodes can be described as centres. Some of these centres are real production and employment centres, and some are artificial centres with zero production. Thus, an income variable can be attached to each of these centres which we term "artificial income" $\left(Y_{j}^{*}\right)$, defined as in equation (7) below. This income is net of income at the appropriate centre minus the transportation costs by the fast mode from the node to this centre. As there are five nodes (including the centre) in our model, $Y_{2}^{*}\left(\geq w_{1}\right)$ and $Y_{4}^{*}\left(\geq w_{2}\right)$ represent the artificial income at centre 1 and centre 2, respectively. The equality of these incomes with the real wages offered at the corresponding centres represents the coexistence of the centres as both production and employment centres. However, when one of the artificial incomes is higher than the real wages offered at the corresponding centre, this implies that the centre ceases to be a production centre. This means that this centre is dominated by the other centre: it serves as a transfer node to the dominant node. Households find commuting to the dominant centre profitable, making it the sole production centre. The introduction of the artificial income here helps to reduce the whole analysis of the model to a one-transport case, by eliminating the second mode of transport at this level, and thus we have: 
$Y_{j}^{*}=\max _{i}\left(w_{i}-T_{f}\left(r_{j i}\right) \quad j \in J\right.$ and $i \in I$,

where $T_{f}\left(r_{j i}\right)$ represents the transportation costs from node $j$ to centre $i$ by the fast mode. In the simple linear cost function $T_{f}\left(r_{j i}\right)=k_{f} \times\left\|r_{i}-r_{j}\right\|$. For the rest of our analysis, we adopt this linear transport cost function.

\section{(a) Residential land rent:}

Once the edge of the node is determined, residential areas face a downward-sloping rent curve with distance. Thus, we observe both distances: distance from the centre, and distance from the station, determining the land rent. In addition to the distance effect, the importance of the centres as explained by the level of wages paid at the centres, also determines the rent of residential land. Due to the bidding nature of rent, the prevailing land rent at any location is the maximum of the rent curves corresponding to each of the transport nodes in the linear city. The bid rent, max bid lot size, and density functions corresponding to each of the nodes are given by:

$$
\begin{aligned}
& \Psi_{j}(r, u)=\alpha^{\alpha / \beta} \beta\left(Y_{j}^{*}-k_{s}\left\|r_{j}-r\right\|\right)^{1 / \beta} e^{-u / \beta} ; \\
& S_{j}(r, u)=\beta\left(Y_{j}^{*}-k_{s}\left\|r_{j}-r\right\|\right) / \Psi_{j}(r, u) ; \\
& \rho_{j}(r, u)=1 / S_{j}(r, u) .
\end{aligned}
$$

The residential bid rent, residential lot size, and settlement densities are not defined within the centres. In the centres, commercial rents always exceed residential rents. The prevailing values in the city are the maximum or minimum envelopes of the above variables corresponding to the nodes.

$$
\begin{aligned}
& R R(r, u)=\max _{j}\left(\Psi_{j}(r, u)\right) j \in\{1,2, \ldots, 5\} ; \\
& S(r, u)=\min _{j}\left(S_{j}(r, u)\right) j \in\{1,2, \ldots, 5\} ; \\
& \rho(r, u)=\max _{j}\left(\rho_{j}(r, u)\right) j \in\{1,2, \ldots .5\} .
\end{aligned}
$$

\section{(b) Commercial land rent}

In the production process of the firm(s) operating at the employment centre, land is one of the inputs in the production of floor space. Because transportation costs inside the centre are assumed 
to be zero, a uniform land rent for commercial use is obtained. The nature of the commercial land rent in the centres is determined by the nature of the land market. In a competitive market situation, the commercial land rents are equal to the corresponding residential land rents at the edges of the centres. However, when the land market is regulated in some different ways, a different result may be obtained. We will give more attention to the effect of the nature of the land market in the analysis of land rent in the following sections.

\section{(c) Prevailing land rent and land use}

In the model we distinguish three types of land use: commercial; residential; and agriculture. The agricultural land rent is given exogenous to the model. This uniform commercial land rent bids out the downward-sloping residential rent curve which start at the edge of the centre. Thus, the prevailing rent curve at any point in space is the maximum of the residential, commercial and agriculture land rents, which can be written as:

$$
R(r)=\max _{i \in I, j \in J}\left(\Psi_{j}(r, u), R C_{i}, R A\right) .
$$

\subsection{Producers' equilibrium: cost minimization}

At the production side, the model incorporates the assumption of Sivitanidou and Wheaton (1992), in which the two centres make products that utilize labour and floor space and that are sold outside city. Floor space at the centres $\left(\mathrm{Qs}_{\mathrm{i}}\right)$ is produced by making use of capital $\left(\mathrm{K}_{\mathrm{i}}\right)$ and land $\left(\mathrm{L}_{\mathrm{i}}\right)$ with constant returns to scale Cobb Douglas production function, as given below:

$Q s_{i}=K^{\delta} L^{1-\delta}$

Centres are assumed to have constant floor space demand per worker $\left(a_{s}=\frac{Q s_{i}}{N_{i}}\right)$. Thus, given the price of capital $\left(r_{c}\right)$, rent for floor space is given by:

$$
R F_{i}=\frac{R C_{i} L_{i}+r_{c} K_{i}}{a_{s} N_{i}}, \quad i \in I
$$

The cost minimizing input bundle is given by: 
$K_{i}=a_{s} N_{i}\left(\frac{\delta R C_{i}}{(1-\delta) r_{c}}\right)^{(1-\delta)}, \quad i \in I ;$

$L_{i}=a_{s} N_{i}\left(\frac{(1-\delta) r_{c}}{\delta R C_{i}}\right)^{\delta}, \quad i \in I$.

Therefore, the long-run cost-minimizing floor space rent is:

$R F_{i}=r_{c}^{\delta} \delta^{-\delta}(1-\delta)^{(\delta-1)} R C_{i}^{(1-\delta)}, \quad i \in I$.

The production equilibrium condition between the centres thus states that the costs per worker at each of the centres should be equal. The element of cost advantage here can be regarded as internal cost savings in the production process, or otherwise as external subsidy:

$w_{1}-w_{2}=R F_{2} a_{s}-R F_{1} a_{s}+C A$.

Centres operate at a zero profit. They are price takers for the goods or services supplied on the national market:

$p r t+C A-w_{1}-R F_{1} \times a_{s}=0 ;$

$p r t-w_{2}-R F_{2} \times a_{s}=0$.

\subsection{Indifference location}

The number of households in the city $(N)$ is an important element in the determination of the equilibrium conditions. It is assumed that the city does not continue beyond the fringes of the residential areas. The total number of households in the city is calculated as the integral of household density between the city fringes. The left $\left(f^{\llcorner}\right)$and right $\left(f^{+}\right)$fringes of the city are locations where the residential rent corresponding to the nearest node and the agricultural rent intersect, which can be written as:

$\Psi_{1}\left(f^{-}, u\right)=R A ;$

$\Psi_{5}\left(f^{+}, u\right)=R A$

$N=\int_{f^{-}}^{f^{+}} \rho(r, u) d r$. 
But, in order to determine the number of households commuting to each of the centres, we need another critical location, i.e. is the indifference location between the centres. An important property of the introduction of a second mode in the linear city is that it opens the possibility of cross-commuting. This means that households residing in a range of locations will be left indifferent between commuting to any of the centres. In such a situation, the expected number of households commuting to the centres will be distributed equally, leaving the indifference point necessary for the analysis still effective. This assumption constrains the asymmetric cross commuting case. Our analysis will be limited to symmetric cross-commuting, in cases of wider indifference locations. The rent curve corresponding to the middle station in our model certainly plays a part in determining the indifference location. However, to which side of the station this point lays is affected by a wide range of factors, of which, in this model, we will be limited to the cost advantage (CA) of the centres in their production process. Thus, the indifference location $(f)$ can be given by:

$$
\begin{array}{lll}
\Psi_{3}(f, u)=\Psi_{4}(f, u) & \text { if } & C A>0 \\
f=r_{3} & \text { if } & C A=0 \\
\Psi_{3}(f, u)=\Psi_{2}(f, u) & \text { if } & C A<0 .
\end{array}
$$

Given that (f) is the indifference location between the centres, the number of households working in each centre is given by:

$$
\begin{aligned}
& N_{1}=\int_{f^{-}}^{f} \rho(r, u) d r \\
& N_{2}=\int_{f}^{f^{+}} \rho(r, u) d r .
\end{aligned}
$$

\section{ALTERNATIVE LAND MARKETS}

\subsection{Competitive land market:}

In this model we assume households and firms freely bid against each other for land. At the edges of the centres the commercial and residential rents are equal. The competitive land bidding ensures that landlords will eventually extract the maximum saving that the consumers may enjoy, given the utility level. Because, by assumption, there are no transportation costs inside centres, the commercial rent curve assumes a uniform pattern. Centres situated at pre-specified locations make no profit from production processes. The equilibrium condition for the competitive market 
contains 13 equations in 13 unknowns. The equilibrium conditions for the competitive land market are presented below in Table 2 .

Table 2: Equilibrium conditions

\begin{tabular}{|c|c|c|}
\hline Description & Equation & Previous reference \\
\hline $\begin{array}{l}\text { Equality of residential bid rent and commercial } \\
\text { rent at the edges of employment centres }\end{array}$ & $\begin{array}{l}\Psi_{2}\left(r_{2^{-}}, u\right)=\Psi_{2}\left(r_{2^{+}}, u\right)=R C_{1} \\
\Psi_{4}\left(r_{4^{-}}, u\right)=\Psi_{4}\left(r_{4^{+}}, u\right)=R C_{2}\end{array}$ & $x_{2}$ \\
\hline $\begin{array}{l}\text { Cost-minimizing floor space function at the } \\
\text { centres }\end{array}$ & $\begin{array}{l}R F_{1}=r_{c}^{\beta} \beta^{-\beta}(1-\beta)^{(\beta-1)} R C_{1}^{(1-\beta)} \\
R F_{2}=r_{c}{ }^{\beta} \beta^{-\beta}(1-\beta)^{(\beta-1)} R C_{2}{ }^{(1-\beta)}\end{array}$ & (19), for $i \in I$ \\
\hline Zero profit condition for production centres & $\begin{array}{l}p r t \times p+C A-w_{1}-R F_{1} \times a_{s}=0 \\
p r t \times p-w_{2}-R F_{2} \times a_{s}=0\end{array}$ & $\begin{array}{l}(21) \\
(22)\end{array}$ \\
\hline Commercial land for centres & $\begin{array}{l}L_{1}=a_{s} N_{1}\left(\frac{(1-\delta) r_{c}}{\delta R C_{1}}\right)^{\delta} \\
L_{2}=a_{s} N_{2}\left(\frac{(1-\delta) r_{c}}{\delta R C_{2}}\right)^{\delta}\end{array}$ & (18), for $i \in I$ \\
\hline Number of households attending the centres & $\begin{array}{l}N_{1}=\int_{f^{-}}^{f} \rho(r, u) d r \\
N_{2}=\int_{f}^{f^{+}} \rho(r, u) d r\end{array}$ & $\begin{array}{l}\text { (27) } \\
(28)\end{array}$ \\
\hline Left and right fringes of the linear city & $\begin{array}{l}\Psi_{2}\left(f^{-}, u\right)=R A \\
\Psi_{4}\left(f^{+}, u\right)=R A\end{array}$ & $\begin{array}{l}\text { (23) } \\
(24)\end{array}$ \\
\hline Indifference location between the two centres & $\begin{array}{lll}\Psi_{3}(f, u)=\Psi_{4}(f, u) & \text { if } & C A>0 \\
f=r_{3} & \text { if } & C A=0 \\
\Psi_{3}(f, u)=\Psi_{2}(f, u) & \text { if } & C A<0\end{array}$ & (26) \\
\hline
\end{tabular}

Note: The above 13 system of equilibrium conditions has 13 unknowns $\left\{R F_{1}, R F_{2}, w_{1}, w_{2}\right.$, $\left.R C_{1}, R C_{2}, f, f^{-}, f^{+}, N_{1}, N_{2}, L_{1}, L_{2}\right\}$.

\subsection{A segmented land market}

In this second model, we impose a binding restriction on the commercial land area for one or both of the centres, such that $L_{i}=\mathrm{rl}<L_{i}^{*}$, where $L_{i}^{*}$ is the land area occupied by centre $i$ if no restriction is imposed on it. This restriction affects the commercial land rent, and the relative cost of land versus capital. Thus, at the centre with the commercial area restriction, the land rent is no longer determined by competitive bidding from residential land rent, but is instead based on the 
supply of commercial land rent. With a restricted supply of land, the commercial land rent increases, increasing the relative cost of land to capital in the centre. This results in input substitution of land for capital, thus increasing the capital to land ratio.

If the two centres are constrained for commercial land area, we see that the commercial land rent increases in both centres, leading to capital-intensive production. The investment in the fast transport mode increases the labour supply that can reach the centres. This labour increase, coupled with the constrained commercial land area, will further push up the commercial land rent. The shift in the relative cost of land to capital at the centres leads to capital-intensive production in the centres. An increase in the wage at the centres has the same effect. Leaving out the first two equations which are specially related to competitive market case from Table 2 above, the remaining 11 equations determine the equilibrium conditions for this model. The equilibrium condition in this market situation has 11 equations in 11 unknowns.

\section{MODEL SIMULATIONS, OUTPUT AND DISCUSSION}

On the basis of the model above, we now simulate the results of three transport mode situations for the two land market conditions. With respect to the transport mode, we have looked at the unimodal case and, two bimodal cases: namely, partial and full bimodal. In the partial bimodal case, only centre 1 is served by the fast mode from two stations $b / 2$ miles away from its edges, in addition to the slow mode. On the other hand in the full bimodal case where feasible, both centres are served by the faster mode from the pre-specified stations, in addition to the slow mode. Apart from the nature of the land market, the cost advantage of the centres in their production process is taken as another distinguishing factor in the analysis. Below, we present the simulated rent curves for each of the cases.

\section{Exogenous parameters:}

As an extension of the model presented by Sivitanidou and Wheaton (1992), our model uses the same value for some of the exogenous parameters that they used in their simulation. The remaining variables that relate to the new extension to the model are selected in a way that facilitates comparison. The values are given in Table 3 below. 
Table 3: Value of exogenous parameters

\begin{tabular}{|l|r|}
\hline Parameter & Value \\
\hline Distance between nodes (b/2 mile) & 10.00 \\
\hline Width of the city (mile) & 1.00 \\
\hline$\beta$ in utility function & 0.50 \\
\hline Agricultural rent (\$/acre) & 7500.00 \\
\hline Annual cost of transport & 350.00 \\
\hline - Slow mode $k_{s}(\$)$ & 200.00 \\
\hline - Fast mode $k_{f}(\$)$ & 0.77 \\
\hline$\delta$ in floor space function & 250.00 \\
\hline Floor space per worker $a_{s}$ (sq. ft.) & 7.00 \\
\hline Annual rent of capital $\left(\$ /\right.$ sq. ft.) $r_{c}$ & 1.20 \\
\hline National utility level $u$ & 1.00 \\
\hline Price of non-land consumption & 1.00 \\
\hline Price of production output $(p)$ & 22371.00 \\
\hline Productivity per worker prt & $0 ; 1,000$ \\
\hline Cost advantage $(\mathrm{CA})$ for centre 1 (\$) & 1.80 \\
\hline Commercial land restrictions & 1.80 \\
\hline - Centre 1 (sq. miles) & \\
\hline - Centre 2 (sq. miles) & \\
\hline
\end{tabular}

The graphical and numerical presentations of the simulation output are given in Appendices I and II. The following section discusses the findings. The partial equilibrium model is used to analyse the impact of the three items: land market distortions; the cost advantage of centres; and investments in rail infrastructure.

\subsection{Effect of land market distortions}

The competitive land market makes it possible for the production centres to acquire the required amount of land input for their production process at the competitive land rent. As long as the wage-paying ability is not affected, the competitive land rent level remains the same. This leaves unchanged the relative cost of land and capital, and the capital to land ratio in the production technology of the centres. In contrast, in the segmented market, the level of land restriction (the supply of commercial land) imposed in the centre(s) affects the commercial land rent and residential land rent. The restriction has a direct effect on the relative cost of capital and land. This in turn affects the wage-paying ability of the centres. Therefore, segmentation of the market has an effect on the production technology of the centres. The higher the commercial land restriction imposed on the centres, the higher the relative price of land to capital. Centres will then be increasingly capital-intensive in their production process. This leads to higher commercial 
land rents in the centres. In real life, this fact is visible in the form of high-rise buildings in central areas of cities. On the other hand, the commercial land restriction reduces the wage-paying ability of the centres. Thus, at each location, residential land rents will be lower than the corresponding locations under the competitive land market situation.

As Table 1 shows, the occurrence of restrictions on commercial land in the centres leads to an increase in total commercial land receipts (.277 versus .273): the increase in rent per unit dominates the decrease in area. This seems to indicate that restrictions on commercial land use improve opportunities to use land rents as a source of finance for infrastructure. However, the increase in commercial land rents is more than off-set by a decrease in residential land rents (3.758 versus 3.786).

\subsection{Effect of cost advantage}

Next, we look at the effects of assumed differences in the production processes of the centres. Cost advantages in the production process are assumed here to account for this difference. An exogenous difference in the cost of production between the centres (CA) is capitalized into differences in commercial space and wages. However, the level of capitalization differs between the market situations considered. In the competitive market situation, wage capitalization accounts for most of the capitalization. But, in the segmented market case the difference in commercial rent of the advantaged centre accounts for an increasing proportion.

\subsection{Effect of transportation investment}

The main focus of this paper is to determine the effect of investment in a fast mode on the land market. To trace the effect of the transportation investment, we compare three cases: namely, 1) the base case (i.e. the unimodal case); 2) partial bimodal case, where only one centre is served by the fast mode from two stations; and 3) the complete bimodal case, where the two centres are served by the fast mode from three stations. Investment in the fast transport mode makes commuting to the centres possible from a wider range of locations. Hence, the city size is enlarged by claiming land from agricultural use outside the city. In addition, the fast mode stations attract denser residential settlement, which contributes to the population increase in the city. In general, the effect of the investment in fast transport has a different effect for the two land-market structures. In the competitive market, the investment does not affect the level of wage paying ability of the centres. However, the average residential land rents increase as a result 
of an increase in the density of settlement around the stations (compare the unimodal and complete bimodal case in Tables AII1 and AII2 in Appendix II). On the other hand, because of the unchanged wage level, the commercial land rent is not affected. The capital to land ratio that represents the technology of the centres remains the same. However, the size of the centres increases due to the increase in the number of employees arriving at the centres. In the segmented market case, some effects occur on both the residential and commercial sides. The additional labour made possible by the fast mode has the same direction of effect on the residential and the commercial land rents in the city (as was discussed earlier in this paragraphs). The important feature here is that, due to the increase in the demand of commercial land (as a result of the increase in labour), coupled with the limited supply of land, the commercial land rent increases. This makes the non-labour input into the production process costly. At the break-even level, the wage-paying ability of the centres declines. As a result, the average residential land rent declines compared with the case of the competitive market (1.34 versus 1.36).

We conclude from Table 1 that, under a distorted land market, total commercial rent increase in the city, as a result of the introduction of rail, is higher than in a competitive market (.302-.273 versus .314-.277). However, total residential rents decrease substantially due to segmentation, and thus the net effect on total rent receipts is clearly less favourable under distorted land markets than under competitive land markets. Hence, if capturing rents as a means to finance infrastructure is feasible at all locations, the competitive market offers the best opportunities. But, if these opportunities are only possible at commercial locations, the conclusion may change.

\section{(a) Competitive position of centres}

The effect of partial investment in the faster transport mode on the relative competitive position of the centres can be seen by allowing only one centre to benefit from such service. We can see this effect from Tables AII.1 and AII.2 (in Appendix II) under the partial bimodal case. In the simulation, we allow a partial fast mode transport investment to serve only centre 1 . In general, the fast mode leads to the growth of city size and an increase in total rent in both market situations. However, it affects the average and total rent of the individual centres differently. In the competitive market, the investment leads to the decline of average and total residential land rent in the disadvantaged centre. In this case, even though the average commercial land rent is not affected, the total commercial land rent of the centre declines. In contrast, in the segmented market case, the effect of the investment leads to a decline for both average and total commercial and residential land rents. This shows that the advantaged centre grows at the expense of the 
disadvantaged centre by claiming more of the households residing in the area between the centres.

\section{(b) Land rent loss or gain as a result of rail investment}

In the competitive land market, due to the flexible size of centres, the comparison of areas that lose or gain rent as a result of transport investment is difficult to trace graphically. However, a clearer comparison can be made in the segmented land market. We will focus on the residential land rent. Residential land rent is directly affected by the wage-paying ability at the centres. As we go from the unimodal case to the partial bimodal situation, we see residential land rent gain around the stations and the centre with no fast mode connection. However, the immediate area around the employment centre with fast rail connection experience rent loss due to the decline in the wage-paying ability of the centre. Changes in any of the variables that affect the level of wage-paying ability of centres have an impact on the level of rent loss or gain that areas experience as a result of moving from one rail investment scheme to the other. (see Figure AII.1.)

\section{(c) Effects of mixed land market}

We can also allow a mixed land market for the two centres in the city and see what effect this has. The simulated result is given in Table AII.2 in the appendix II. Generally, as expected, the outcome is in between the out comes of the two uniform land market situations. In the unimodal and complete bimodal transport cases, alternating the land market situation between centres results in perfect symmetry. However, the partial bimodal transport case has some special features. Higher land rent receipts are achieved when the centre served by the railway has a competitive land market.

\section{CONCLUSION}

From the discussion above, we can conclude that each area of change on the model has a unique effect on the model equilibrium result. Due to possible transport cost saving, railway stations serve as centres which have an artificial wage and a corresponding residential land bid curve. Generally, investment in the fast mode results in: city growth both in terms of area size and population; increase in rent receipts; and denser residential settlements. However the effect of the investment for individual centres and their corresponding residential areas depends on the underlying land market assumptions and the level of investment. 
As we progressively invest in railways from a unimodal to a complete bimodal situation, we observe rent losing and gaining phenomena, along segments of the city in the segmented land market situation.

When land rents are captured as a source of investment for railway infrastructure, the increase in total rents is highest in the situation of a competitive land market. But it is important to realise that the rent increases are spread widely in the urban metropolitan area, which may make them difficult to collect in real-world situations. Of course the most focussed increases of rents take place near the railway stations. Of special importance is the finding that, in the case of segmented markets, the total commercial rent receipts are higher than with a competitive land market. Thus, as long as rent capturing is limited to commercial land use, the segmented land market is not as unfavourable as one might expect. The issue of distortions of land markets is important because these distortions may have decisive impacts on long-run changes in transport demand in response to changes in the transport system. The present paper shows how such distortions can be addressed in an appropriate way.

Investment plans in a mixed land market situation for the complete bimodal cases result in symmetry. However, in the partial bimodal plan, connecting the centre under a competitive land market results in higher land market receipts.

In the present paper, we have analysed the impact of a second transport mode on the dynamics of centres in a metropolitan area, under the assumption that the additional infrastructure may reinforce or weaken the existing commercial centres. However, transport investments may also have far reaching effects on spatial structure, since they may stimulate the emergence of new centres. This theme of the formation of new centres has not been addressed in the present paper. Instead, we have focussed explicitly on the demand for commercial land and the implications of distortions for the land market. Analysing the possible emergence of additional centres falls outside the scope of this model, but is certainly a promising extension. In order to achieve this aim, the model should be developed in the direction of a more explicit treatment of production processes and agglomeration economies. 


\section{Appendix I: graphical presentation of simulation result}

Figure AI.1 competitive market

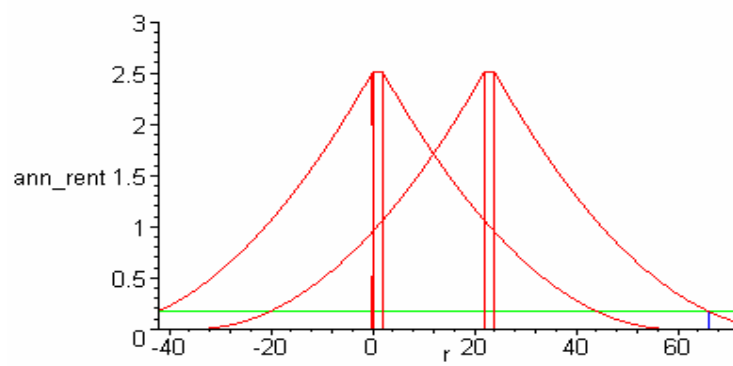

a) Rent curves for the unimodal-bicentric city case without a cost advantage between centres: a competitive market situation

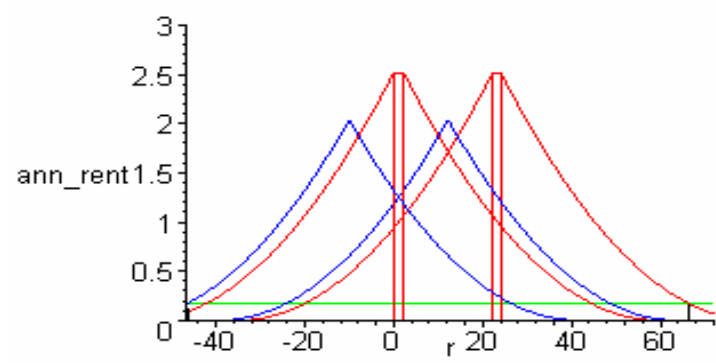

b) Rent curves for the partial bimodal city case, without a cost advantage between centres: a competitive market situation

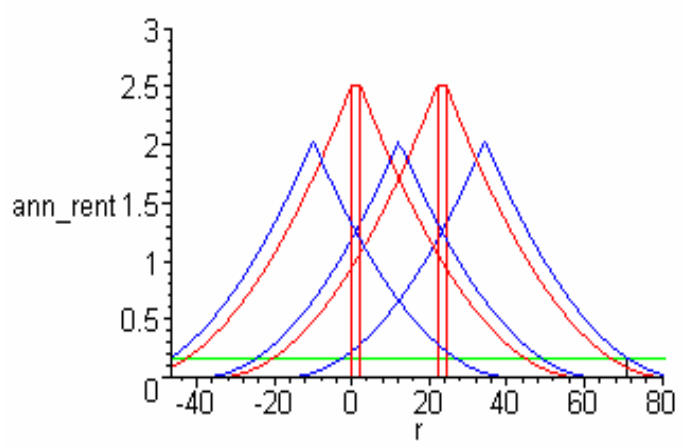

c) Rent curves for the complete bimodal city case, without a cost advantage between centres: a competitive market situation
Figure AI.2 segmented market

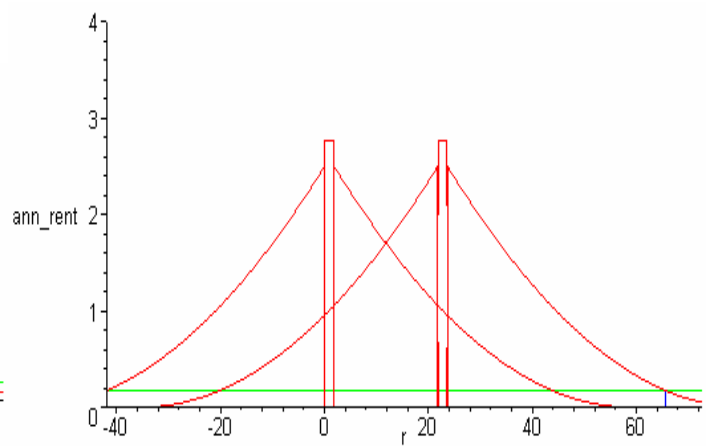

a) Rent curves for the unimodal-bicentric city case, without a cost advantage between centres: a segmented market situation

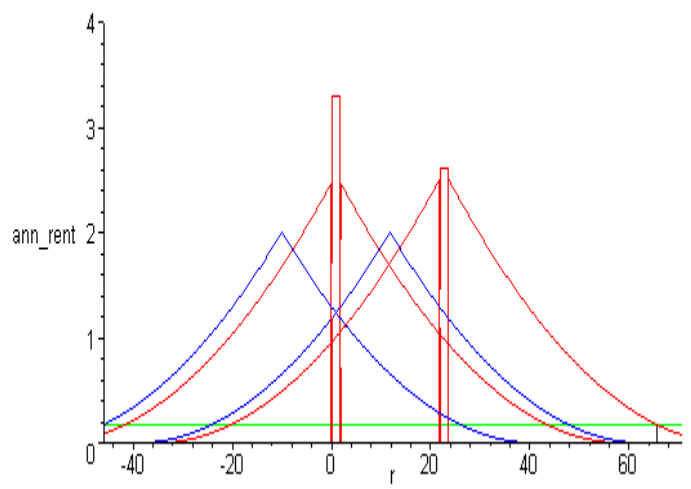

b) Rent curves for the partial bimodal city case, without a cost advantage between centres: a segmented market situation

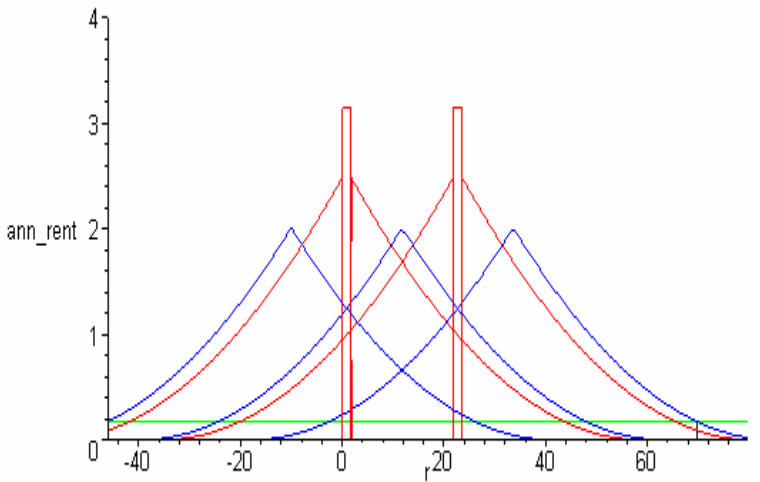

c) Rent curves for the fully improved bimodal city case, without a cost advantage between centres: a segmented market situation 
Appendix II: Numerical presentation of simulation output

Table AII.1: Simulation output for both markets in the case of no cost advantage between centres

\begin{tabular}{|c|c|c|c|c|c|c|c|c|c|c|c|c|c|c|c|c|}
\hline \multirow[b]{2}{*}{ CASES } & \multirow[b]{2}{*}{ Centre } & \multirow[b]{2}{*}{$\begin{array}{l}\text { Fast } \\
\text { mode }\end{array}$} & \multicolumn{2}{|c|}{ Exogenous Para. } & \multicolumn{12}{|c|}{ Endogenous Variable } \\
\hline & & & $\begin{array}{l}\text { Comm. } \\
\text { Land } \\
\text { Area } \\
\text { Sq. miles } \\
\end{array}$ & $\begin{array}{l}\text { Annual } \\
\text { Wages } \\
\$ \\
\end{array}$ & $\begin{array}{l}\text { Resid. } \\
\text { Land } \\
\text { Sq. miles }\end{array}$ & $\begin{array}{l}\text { Labour } \\
\text { Supply }\end{array}$ & $\begin{array}{l}\text { Comm. } \\
\text { land } \\
\text { sq. miles }\end{array}$ & $\begin{array}{l}\text { Capital } \\
\text { Land } \\
\text { ratio }\end{array}$ & $\begin{array}{l}\text { Annual } \\
\text { Resid. } \\
\text { Rent } \\
\text { at centre } \\
\text { edge } \\
\text { \$/sq. ft. } \\
\end{array}$ & $\begin{array}{l}\text { Annual } \\
\text { Com. } \\
\text { Rent } \\
\text { at centre } \\
\text { Edge } \\
\text { \$/sq. ft. }\end{array}$ & $\begin{array}{l}\text { Aver. } \\
\text { Annual } \\
\text { Resid. } \\
\text { Rent } \\
\\
\text { \$/sq. ft. }\end{array}$ & $\begin{array}{l}\text { Aver. } \\
\text { Annual } \\
\text { Com. } \\
\text { Rent } \\
\\
\text { \$/sq. ft. }\end{array}$ & $\begin{array}{l}\text { Annual } \\
\text { Floor } \\
\text { space } \\
\text { rent } \\
\$ \text { sq. ft. }\end{array}$ & $\begin{array}{l}\text { Total } \\
\text { Resid. } \\
\text { Rent } \\
\text { Bill. \$ } \\
\end{array}$ & $\begin{array}{l}\text { Total } \\
\text { Com } \\
\text { Rent } \\
\text { Bill. \$ } \\
\end{array}$ & $\begin{array}{l}\text { Total } \\
\text { Rent }\end{array}$ \\
\hline \multicolumn{17}{|l|}{ Unimodal } \\
\hline \multirow[t]{3}{*}{ Competitive market } & 1 & no & & 20,000 & 52.17 & 250,000 & 1.95 & 1.20 & 2.51 & 2.51 & 1.30 & 2.51 & 9.48 & 1.893 & 0.136 & 2.029 \\
\hline & 2 & no & & 20,000 & 52.17 & 250,000 & 1.95 & 1.20 & 2.51 & 2.51 & 1.30 & 2.51 & 9.48 & 1.893 & 0.136 & 2.029 \\
\hline & $\begin{array}{l}\text { Total/ } \\
\text { average }\end{array}$ & & & & 104.34 & 500,000 & 3.90 & & & & 1.30 & 2.51 & & 3.786 & 0.273 & 4.058 \\
\hline \multirow[t]{3}{*}{ Segmented market } & 1 & no & 1.80 & 19,947 & 52.02 & 248,751 & 1.80 & 1.32 & 2.50 & 2.77 & 1.30 & 2.77 & 9.70 & 1.879 & 0.139 & 2.018 \\
\hline & 2 & no & 1.80 & 19,947 & 52.02 & 248,751 & 1.80 & 1.32 & 2.50 & 2.77 & 1.30 & 2.77 & 9.70 & 1.879 & 0.139 & 2.018 \\
\hline & $\begin{array}{l}\text { Total/ } \\
\text { average }\end{array}$ & & & & 104.04 & 497,502 & 3.60 & & & & 1.30 & 2.77 & & 3.758 & 0.277 & 4.035 \\
\hline \multicolumn{17}{|l|}{ Partial bimodal } \\
\hline \multirow[t]{3}{*}{ Competitive market } & 1 & yes & & 20,000 & 58.60 & 290,195 & 2.26 & 1.20 & 2.51 & 2.51 & 1.38 & 2.51 & 9.48 & 2.252 & 0.158 & 2.410 \\
\hline & 2 & no & & 20,000 & 50.03 & 237,352 & 1.85 & 1.20 & 2.51 & 2.51 & 1.28 & 2.51 & 9.48 & 1.786 & 0.129 & 1.916 \\
\hline & $\begin{array}{l}\text { Total/ } \\
\text { average }\end{array}$ & & & & 108.63 & 527,547 & 4.11 & & & & 1.34 & 2.51 & & 4.038 & 0.288 & 4.326 \\
\hline \multirow[t]{3}{*}{ Segmented market } & 1 & yes & 1.80 & 19,846 & 57.97 & 285,107 & 1.80 & 1.58 & 2.47 & 3.30 & 1.36 & 3.30 & 10.10 & 2.196 & 0.166 & 2.361 \\
\hline & 2 & no & 1.80 & 19,979 & 50.16 & 238,003 & 1.80 & 1.25 & 2.51 & 2.61 & 1.28 & 2.61 & 9.57 & 1.791 & 0.131 & 1.922 \\
\hline & $\begin{array}{l}\text { Total/ } \\
\text { average }\end{array}$ & & & & 108.13 & 523,110 & 3.60 & & & & 1.34 & 2.99 & & 3.986 & 0.297 & 4.283 \\
\hline \multicolumn{17}{|l|}{ Complete bimodal } \\
\hline \multirow[t]{3}{*}{ Competitive market } & 1 & yes & & 20,000 & 56.46 & 275,860 & 2.15 & 1.20 & 2.51 & 2.51 & 1.36 & 2.51 & 9.48 & 2.135 & 0.151 & 2.287 \\
\hline & 2 & yes & & 20,000 & 56.46 & 275,860 & 2.15 & 1.20 & 2.51 & 2.51 & 1.36 & 2.51 & 9.48 & 2.135 & 0.151 & 2.287 \\
\hline & $\begin{array}{l}\text { Total/ } \\
\text { average }\end{array}$ & & & & 112.92 & $\mathbf{5 5 1 , 7 2 0}$ & 4.30 & & & & 1.36 & 2.51 & & 4.271 & 0.302 & 4.573 \\
\hline \multirow[t]{3}{*}{ Segmented market } & 1 & yes & 1.80 & 19,876 & 56.10 & 273,894 & 1.80 & 1.50 & 2.48 & 3.14 & 1.34 & 3.14 & 9.98 & 2.100 & 0.157 & 2.257 \\
\hline & 2 & yes & 1.80 & 19,876 & 56.10 & 273,894 & 1.80 & 1.50 & 2.48 & 3.14 & 1.34 & 3.14 & 9.98 & 2.100 & 0.157 & 2.257 \\
\hline & $\begin{array}{l}\text { Total/ } \\
\text { average }\end{array}$ & & & & 112.21 & 547,788 & 3.60 & & & & 1.34 & 3.14 & & 4.199 & 0.314 & 4.514 \\
\hline
\end{tabular}


Table AII.2: Simulation output for both the three transport cases with mixed land markets between the centres.

\begin{tabular}{|c|c|c|c|c|c|c|c|c|c|c|c|c|c|c|c|c|}
\hline \multirow[b]{2}{*}{ CASES } & \multirow[b]{2}{*}{ Centre } & \multirow[b]{2}{*}{$\begin{array}{l}\text { Fast } \\
\text { mode }\end{array}$} & \multicolumn{2}{|c|}{ Exogenous Para. } & \multicolumn{12}{|c|}{ Endogenous Variables } \\
\hline & & & $\begin{array}{l}\text { Comm. } \\
\text { Land } \\
\text { Area } \\
\text { Sq. miles }\end{array}$ & $\begin{array}{l}\text { Annual } \\
\text { Wage } \\
\$ \\
\end{array}$ & $\begin{array}{l}\text { Resid. } \\
\text { Land } \\
\text { Sq. miles }\end{array}$ & $\begin{array}{l}\text { Labour } \\
\text { Supply } \\
\end{array}$ & $\begin{array}{l}\text { Comm. } \\
\text { land } \\
\text { sq. miles }\end{array}$ & $\begin{array}{l}\text { Capital } \\
\text { Land } \\
\text { Ratio }\end{array}$ & $\begin{array}{l}\text { Annual } \\
\text { Resid. } \\
\text { Rent } \\
\text { at centre } \\
\text { edge } \\
\$ / \text { sq. ft. } \\
\end{array}$ & $\begin{array}{l}\text { Annual } \\
\text { Com. } \\
\text { Rent } \\
\text { at centre } \\
\text { Edge } \\
\$ / \text { sq. ft. }\end{array}$ & $\begin{array}{l}\text { Aver. } \\
\text { Annual } \\
\text { Resid. } \\
\text { Rent } \\
\\
\text { \$/sq. ft. }\end{array}$ & $\begin{array}{l}\text { Aver. } \\
\text { Annual } \\
\text { Com. } \\
\text { Rent } \\
\\
\$ \text { /sq. ft. }\end{array}$ & $\begin{array}{l}\text { Annual } \\
\text { Floor space } \\
\text { rent } \\
\text { \$/sq. ft. }\end{array}$ & $\begin{array}{l}\text { Total } \\
\text { Resid. } \\
\text { Rent } \\
\text { Bill. \$ } \\
\end{array}$ & $\begin{array}{l}\text { Total } \\
\text { Com } \\
\text { Rent } \\
\\
\text { Bill. \$ } \\
\end{array}$ & $\begin{array}{l}\text { Total } \\
\text { Rent } \\
\\
\text { Bill. \$ }\end{array}$ \\
\hline \multicolumn{17}{|l|}{ Unimodal } \\
\hline Competitive market & 1 & no & & 20,000 & 52.17 & 250,002 & 1.95 & 1.20 & 2.51 & 2.51 & 1.30 & 2.51 & 9.48 & 1.893 & 0.136 & 2.029 \\
\hline \multirow[t]{2}{*}{ Segmented market } & 2 & no & 1.80 & 19,947 & 52.02 & 248,751 & 1.80 & 1.32 & 2.50 & 2.77 & 1.31 & 2.77 & 9.70 & 1.879 & 0.139 & 2.018 \\
\hline & $\begin{array}{l}\text { Total/ } \\
\text { average }\end{array}$ & & & & 104.19 & 498,753 & 3.75 & & & & 1.31 & 2.64 & & 3.772 & 0.275 & 4.047 \\
\hline Segmented market & 1 & no & 1.80 & 19,947 & 52.02 & 248,752 & 1.80 & 1.32 & 2.50 & 2.77 & 1.30 & 2.77 & 9.70 & 1.879 & 0.139 & 2.018 \\
\hline \multirow[t]{2}{*}{ Competitive market } & 2 & no & & 20,000 & 52.17 & 250,001 & 1.95 & 1.20 & 2.51 & 2.51 & 1.29 & 2.51 & 9.48 & 1.893 & 0.136 & 2.029 \\
\hline & $\begin{array}{l}\text { Total/ } \\
\text { average }\end{array}$ & & & & 104.19 & 498,753 & 3.75 & & & & 1.30 & 2.64 & & 3.772 & 0.275 & 4.047 \\
\hline \multicolumn{17}{|l|}{ Partial bimodal } \\
\hline Competitive market & 1 & yes & & 20,000 & 58.63 & 290,350 & 2.26 & 1.20 & 2.51 & 2.51 & 1.38 & 2.51 & 9.48 & 2.253 & 0.158 & 2.412 \\
\hline \multirow[t]{2}{*}{ Segmented market } & 2 & no & 1.80 & 19,982 & 49.95 & 236,792 & 1.80 & 1.24 & 2.51 & 2.60 & 1.28 & 2.60 & 9.56 & 1.780 & 0.130 & 1.910 \\
\hline & $\begin{array}{l}\text { Total/ } \\
\text { average }\end{array}$ & & & & 108.58 & 527,142 & 4.06 & & & & 1.33 & 2.55 & & 4.034 & 0.288 & 4.322 \\
\hline Segmented market & 1 & yes & 1.80 & 19,846 & 57.94 & 284,938 & 1.80 & 1.58 & 2.47 & 3.30 & 1.36 & 3.30 & 10.10 & 2.194 & 0.165 & 2.360 \\
\hline \multirow[t]{2}{*}{ Competitive market } & 2 & no & & 20,000 & 50.25 & 238,674 & 1.86 & 1.20 & 2.51 & 2.51 & 1.29 & 2.51 & 9.48 & 1.798 & 0.130 & 1.928 \\
\hline & $\begin{array}{l}\text { Total/ } \\
\text { average }\end{array}$ & & & & 108.19 & 523,612 & 3.66 & & & & 1.33 & 2.90 & & 3.992 & 0.296 & 4.287 \\
\hline \multicolumn{17}{|l|}{ Complete bimodal } \\
\hline Competitive market & 1 & yes & & 20,000 & 56.46 & 276,985 & 2.16 & 1.20 & 2.51 & 2.51 & 1.34 & 2.51 & 9.48 & 2.249 & 0.151 & 2.400 \\
\hline \multirow[t]{2}{*}{ Segmented market } & 2 & yes & 1.80 & 19,876 & 56.10 & 273,985 & 1.80 & 1.50 & 2.48 & 3.14 & 1.35 & 3.14 & 9.98 & 1.985 & 0.157 & 2.142 \\
\hline & $\begin{array}{l}\text { Total/ } \\
\text { average }\end{array}$ & & & & 112.56 & 550,970 & 3.96 & & & & 1.34 & 2.80 & & 4.234 & 0.308 & 4.542 \\
\hline Segmented market & 1 & yes & 1.80 & 19,876 & 56.10 & 273,985 & 1.80 & 1.50 & 2.48 & 3.14 & 1.35 & 3.14 & 9.98 & 1.985 & 0.157 & 2.142 \\
\hline \multirow[t]{2}{*}{ Competitive Market } & 2 & yes & & 20,000 & 56.46 & 276,985 & 2.16 & 1.20 & 2.51 & 2.51 & 1.34 & 2.51 & 9.48 & 2.249 & 0.151 & 2.400 \\
\hline & $\begin{array}{l}\text { Total/ } \\
\text { average }\end{array}$ & & & & 112.56 & 550,970 & 3.96 & & & & 1.34 & 2.80 & & 4.234 & 0.308 & 4.542 \\
\hline
\end{tabular}




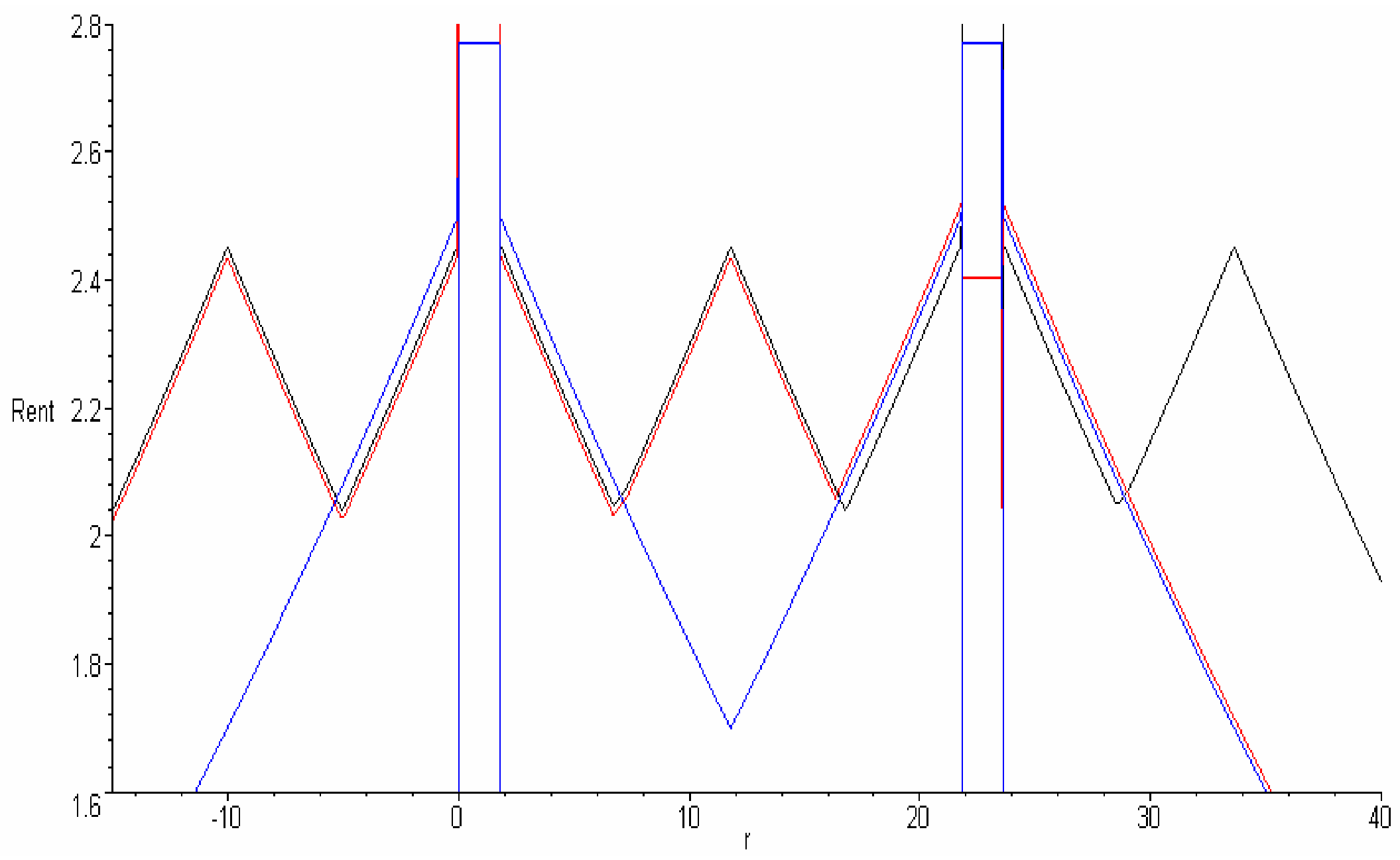

Residential rent curve: unimodal case.

Residential rent curve: partial bimodal case.

Residential rent curve: complete bimodal case.

Figure AII.1 Residential land rent along the linear city for the three categories 


\section{References}

Anas, Alex and Ikki Kim (1996). "General Equilibrium Models of Polycentric Urban Land Use with Endogenous Congestion and Job Agglomeration", Journal of Urban Economics 40, 232-256.

Anas, Alex, Richard Arnott and Kennet Small (1998). "Urban Spatial Structure", $\underline{\text { Journal of }}$ Economic Literature 36, 1426-1464.

Arnott, Richard (2001). "Urban economic aggregates in monocentric and non-monocentric cities". Unpublished manuscript.

Batten, D. F. (1995). "Network Cities: creative urban agglomerations for the 21 th century", Urban Economics 32, 313-327.

Bollinger, C. and K. Ihlanfeldt (1997). "The impact of rapid rail transit on economic development: The case of Atlanta's MARTA", Journal of Urban Economics, 42, 179-204.

Bowes, David R. and Keith R. Ihlanfeldt (2001). "Identifying the Impacts of Rail Transit Stations on Residential Property Values", Journal of Urban Economics, 50, 1-25.

Clark, William A. V. and Marrianne Kuijpers-Linde (1994). "Commuting in Restructuring Urban Regions", Urban Studies 31, 465-483.

Craig, Steven G. and Pin T. Ng (2001). "Using quantile smoothing splines to identify employment subcenters in a multicentric urban area", Journal of Urban Economics. 49 , 100-120.

Dieleman, F.M. and A. Faludi (1998). "Randstad, Rhine-Ruhr and Flemish Diamond as one polynucleated macro-region", Tijdschrift voor Economische en Sociale Geografie 89, pp. 320-327.

Fujita, Masahisa (1989). "Urban Economic theory: Land Use and City Size". New York: Cambridge University press.

Fujita, Masahisa, Paul Krugman and Anthony J. Venables (1999). "The Spatial Economy: Cities, Regions and International Trade". London: the MIT Press .

Garreau, Joel (1988). Edge City: Life on the New Frontier. New York: Doubleday.

Giulliano, Genevieve and Kenneth A Small (1991). "Subcenters in the Los Angeles Region", Regional Science and Urban Economics 21, 163-182.

Glaeser, Edward L. and Matthew E. Kahn (2003). "Sprawl and Urban Growth". Handbook of Urban and Regional Economics Vol. 4.

Helsley, Robert W. and Arthur M. Sullivan (1991). "Urban Subcentre Formation”, Regional Science and Urban Economics 21, 255-275. 
McDonald, John F. (1989). "Econometric Studies of Urban Population Density: A Survey", Journal of Urban Economics 26, 361-385.

McMillen, Daniel P. (2001). "Polycentric Urban structure: The Case of Milwaukee", Economic Perspectives 25, 15-27.

Modarres, Ali (2003). "Polycentricity and Transit Service", Transportation Research Part A 37, 841-864.

Musterd, Sako and Ingrid van Zelm (2001). "Polycentricity, Household and the Identity of

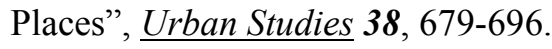

Roback, Jennifer (1982). "Wage, Rent and the Quality of Life", The Journal of Political Economy 90, 1257-1278.

Sasaki, Komei (1989). "Transportation System Change and Urban Structure in Two Transport Mode Setting", Journal of Urban Economics 25, 346-367.

Schwanen, Tim, Frans M. Dieleman and Martin Dijst (2001). "Travel Behaviour in Dutch Monocentric and Polycentric Urban Systems”, Journal of Transport Geography 9, 173186.

Sivitanidou, Rena (1996). "Do Office-Commercial Firms Value Access to Service Employment Centres? A Hedonic Value Analysis within Polycentric Los Angeles", Journal of Urban Economics 40, 125-149.

Sivitanidou, Rena (1997). "Are Center Access Advantages Weakening? The Case of OfficeCommercial Markets", Journal of Urban Economics 42, 79-97.

Sivitanidou, Rena and William C. Wheaton (1992). "Wage and Rent Capitalization in the Commercial Real Estate Market", Journal of Urban Economics 31, 206-229.

Van der Krabben, Edwin and Jan G. Lambooy (1993). "A Theoretical Framework for the Functioning of the Dutch Property Market", Urban Studies 30, 1381-1397.

Wheaton, William C. (1977). "Residential Decentralization, Land Rents, and the Benefits of Urban Transportation Investment", The American Economic Review 67, 138-143.

Wheaton, William C. (2002). "Commuting, Ricardian Rent and House Prices Appreciation in Cities with Dispersed Employment and Mixed Land Use", MIT Department of Economics Working Papers Series.

Wusten, H. van der and A. Faludi (1992). "The Randstad: playground for physical planners", in F. M. Dieleman and S. Musterd (Eds.) The Randstad: A Research and policy Laboratory, pp. 17-38. Dordrecht: Kluwer Academic Publishers. 